\title{
AGRICULTURAL RESIDUES FROM PYROLYSIS AND THEIR APPLICATION IN FLOTATION \\ ZEMĚDĚLSKÉ ODPADY PO PYROLÝZE A JEJICH APLIKACE VE FLOTACI
}

\author{
Peter FEČKO ${ }^{1}$, Jaroslav ZIMA ${ }^{2}$, Zdeňka WITTLINGEROVÁ ${ }^{3}$ \\ ${ }^{1}$ prof., Ing.,CSc., Institute of Environmental Engineering, Faculty of Mining and Geology, \\ Vঙ̌B - Technical University Ostrava, 17. listopadu 2172, 70833 Ostrava, Czech Republic, \\ +420597323575 \\ e-mail: peter.fecko@vsb.cz \\ ${ }^{2}$ Ing., Ministry of Finance of the Czech Republic, Letenská 15, 11810 Praha 1, Czech Republic, \\ +420257041111 \\ e-mail: jaroslav.zima@mfcr.cz \\ ${ }^{3}$ prof., Ing., CSc., Faculty of Environmental Sciences, Czech University of Life Sciences Praque, \\ Kamýcká 129, 16521 Praha 6-Suchdol, +420 224382851 \\ e-mail: wittlingerova@fzp.czu.cz
}

\begin{abstract}
Abstrakt
The paper deals with verification of floatability of a classical collector Montanol 551 and pyrolysis oils that were formed through pyrolysis of agricultural residues from basic industry and used in the flotation of black coal. The results imply that it is possible to produce collectors also from waste agricultural products, which may be applicable in the flotation of black coal.

\section{Abstrakt}

Článek se zabývá ověřením flotovatelnosti klasického sběrače Montanol 551 a pyrolýzních olejů, které vznikly pyrolýzou odpadů ze zemědělské prvovýroby a které byly použity ve flotaci černého uhlí. $Z$ výsledků vyplývá, že i ze zemědělských odpadů lze vyrobit takové sběrače, které se uplatní při flotaci černého uhlí.
\end{abstract}

Key words: flotation, black coal, pyrolysis, agricultural residues

\section{INTRODUCTION}

Coal is a raw material mined for the purposes of numerous industries. At the beginning of the $21^{\text {st }}$ century, the global significance of coal for the civilization is universal. It is used in the metallurgy, power-engineering, chemistry and many other industrial branches.

Currently, mining of black coal is stagnating despite the fact that the consumption of industrial raw materials, the natural resources of which are not renewable and depletable by human action, is increasing. The level of slump in the coal mining is dependent on the development of both international and national conditions. Another significant factor having an influence on this is the fulfilment of the international agreement on gradual reduction of sulphur oxides released into the atmosphere. There is a question how to deal with the issues in connection with the slump in coal mining. One possibility is as perfect preparation of the mined coal as possible as well as maximum utilization of its combustible component.

This trend represents new objectives for mineral dressing - to prepare and comprehensively use the finest coal fractions that originate from the processes of black coal preparation. The created large share of slurry fractions cannot be processed applying classical dressing methods. Those fractions then leave the preparation plant unused, they get into the circuit water of waste water treatment plants, they 
deteriorate the processes of sedimentation, filtration, water courses get polluted and there are losses in valuable raw materials as coal slurries are dewatered in sludge beds or lagoons and they remain unutilized.

The technological procedures of processing of mineral and secondary raw materials, which can be used to deal with the difficult task of ensuring effective, economical and complex utilization of material resources, are flotation, flocculation or their combination, i.e. flotoflocculation.

Thanks to flotation as a technological method of dressing mineral resources and secondary raw materials it is possible to deal with an uneasy task of ensuring an effective, practical and complex utilization of materials sources. Flotation belongs among methods which permit processing of fine, non-homogeneous black-coal slurry.

Coal flotation deals with cleaning the finest fractions of mined coal that originate due to abrasion or disintegration in the course of coal mining and preparation. In practice, it is used only for preparation of cokeable coal. Flotation in coal preparation is a complementary method of other classification processes but very important one and often necessary, especially in connection with ever increasing share of fine fractions due to an extended degree of mechanization of coal mining.

Along with improving the selectivity of flotation it is currently possible to make use of old dumps as the source of material. There was no possible utilization for such dumps in the past. In the course of flotation, very fine fractions get separated, which would otherwise transfer into waste. Next, it is possible to apply flotation to retrieve coal for power-engineering purposes from old settling pits.

This way a significant share of waste constituent is removed from the pulp and thus it gets enriched. Selective flotation can be a final cleaning method or a part of a complex preparation process, which leads to preliminary enrichment of pulp before further preparation process. Application of a suitable collector, which would be ecologically as well as economically interesting, makes an inseparable part of the flotation process. Therefore, it is vital to search for new collectors that would comply with the conditions in question.

The objective of the article was research of new flotation agents that were formed through pyrolysis of agricultural production residues and their comparison with commonly applied collector labelled Montanol 551 used in the black coal preparation plants in the Czech Republic and Poland.

Flotation experiments were carried out using black coal from ČSA Mine, Czech Republic.

\section{MATERIAL, METHOD AND RESULTS}

\subsection{Mineralogical-petrologic Character of the Tested Coal}

Coal polished sections were prepared in compliance with CSN ISO 7404-2 Standard. Maceral analysis was implemented using grain sections in compliance with CSN ISO 7404-3 Standard. Coalpetrographic analyses were carried out using a microscope of NU 2 of Carl Zeiss Jena in oil immersion under the following conditions: $\mathrm{n}_{\mathrm{D}}=1.515, \lambda=546 \mathrm{~nm}$ and temperature of $20^{\circ} \mathrm{C}$. In the photos of the coal polished sections the magnification scale is $50 \mu \mathrm{m}$. Petrographic analyses were carried in the laboratories of Research Institute of Arcelor Mittal, a.s. Ostrava. Table 1 gives an evaluation of petrologic analyses, where the individual symbols mean:
$\mathrm{D}$ - candle coal
$\mathrm{G}$ - gas coal
Ž - medium volatile bituminous coal
$\mathrm{Kž}$ - low-volatile bituminous coal

\author{
Ka - baking coal of the $1^{\text {st }}$ type \\ $\mathrm{Kb}$ - baking coal of the $2^{\text {nd }}$ type \\ $\mathrm{T}$ - anthracite coal
}

$\mathrm{Rn}$ - random reflectivity according to CSN ISO 7404-5 
Tab. 1 Evaluation of petrologic analysis of coal from ČSA Mine

\begin{tabular}{|ll|ll|ll|}
\hline \multicolumn{2}{|c|}{$\begin{array}{c}\text { Maceral analysis } \\
(\%)\end{array}$} & \multicolumn{3}{|c|}{$\begin{array}{c}\text { Type analysis } \\
(\%)\end{array}$} & \multicolumn{2}{c|}{$\begin{array}{c}\text { Vitrinite reflectivity } \\
(\%)\end{array}$} \\
\hline Vitrinite: 49,2 & D: & Ka: & Rn: & 1,028 \\
\hline Inertinite: 44,8 & G: 22 & Kb: & Rmin: & 0,853 \\
\hline Liptinite: 6,0 & Ž: 60 & T: & Rmax: & 1,294 \\
\hline & Kž: 18 & A: & s: & 0,113 \\
\hline
\end{tabular}

Fig. 1 displays the reflectivity of black coal from the ČSA locality. Figure 2 shows a megasporinite grains and Figure 3 shows a grain of kainite and vitrinite.

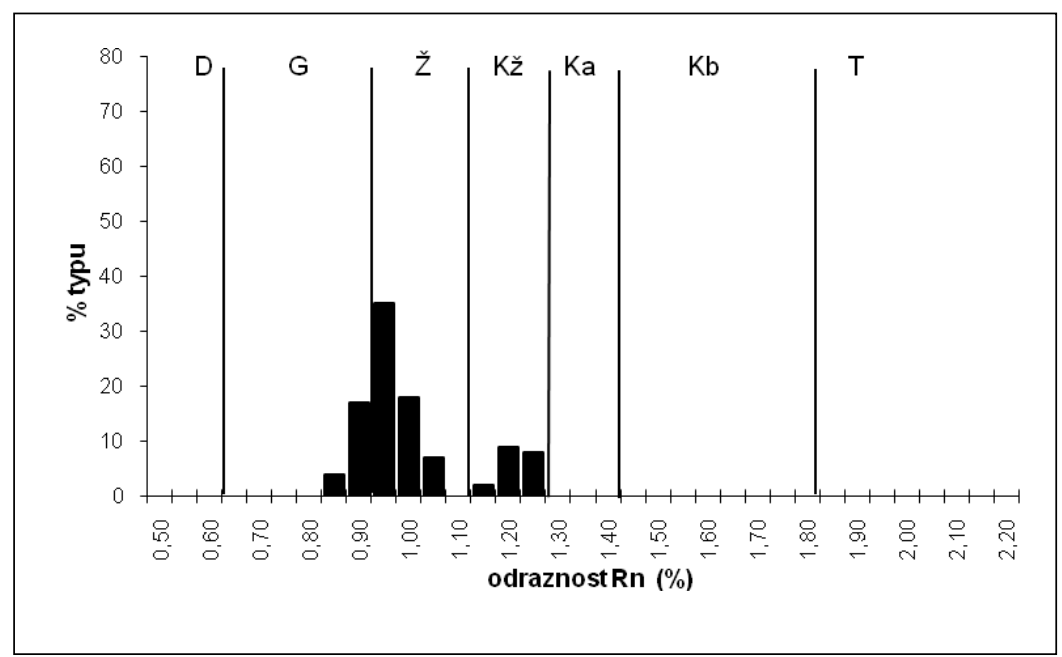

Fig. 1 Reflectivity of ČSA Mine black coal

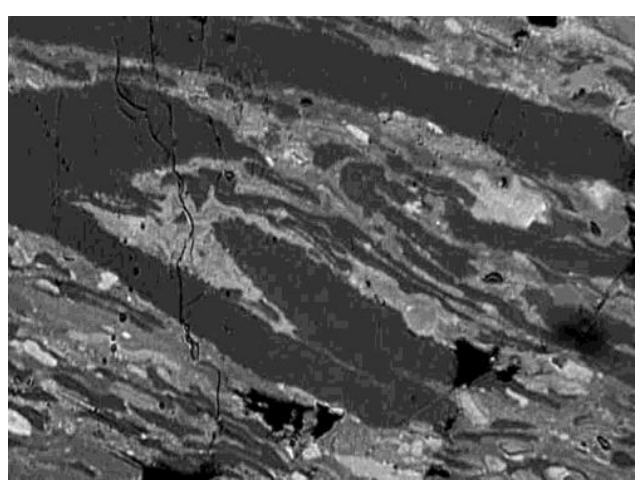

Fig. 2 Megasporinite grain -ČSA Mine

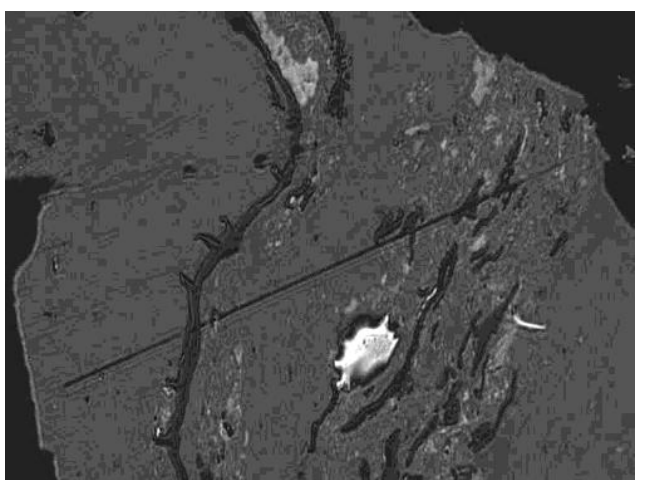

Fig. 3 A grain of cutinite and vitrinite (ČSA Mine)

\subsection{Method and Results of Flotation Tests}

For all the pyrolysis tests a laboratory pyrolytic unit was used, built in IRSM AS CR Prague. Pyrolysis took place in a quartz reactor $(\varnothing 60 \mathrm{~mm}$, length $450 \mathrm{~mm}$ ) placed into a vertical tube oven controlled by a microprocessor. 


\section{Conditions of Pyrolysis:}

Heating rate: $5 \mathrm{~K} \cdot \mathrm{min}^{-1}$ up to the final temperature of $900^{\circ} \mathrm{C}$, soaking time 30 minutes at $900^{\circ} \mathrm{C}$.

The sample weight was $50 \mathrm{~g}$ (grain less than $3 \mathrm{~mm}$ ). For pyrolysis tests we used walnut shells, peach stones, green beans, poppy heads, peanut shells, onion peel, corn leaves and apple tree leaves.

Fig. 4 shows equipment used for the pyrolysis tests.

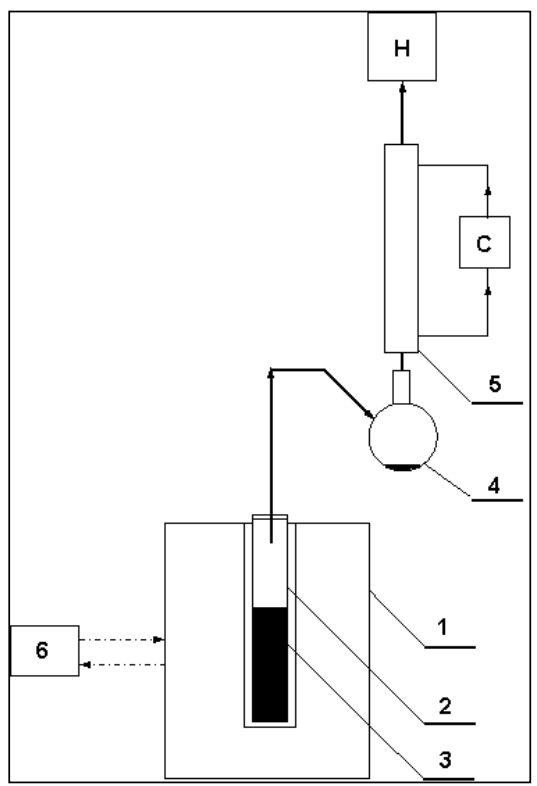

Fig. 4 Laboratory pyrolytic unit

1 - vertical tube oven, 2 - quartz reactor, 3 - pyrolyzed sample, 4 flask with liquid products, 5 - cooler, 6 - programmable temperature control unit, $\mathrm{H}$ - gas holder with gas volume registration, $\mathrm{C}$ - cooling unit

The characteristics of the obtained oils were analyzed in the laboratories of VUCHEM VŠB-TU Ostrava using an infra-red (IR) spectrometer. The results of the IR analyses are in Fig. 5 to 12. 


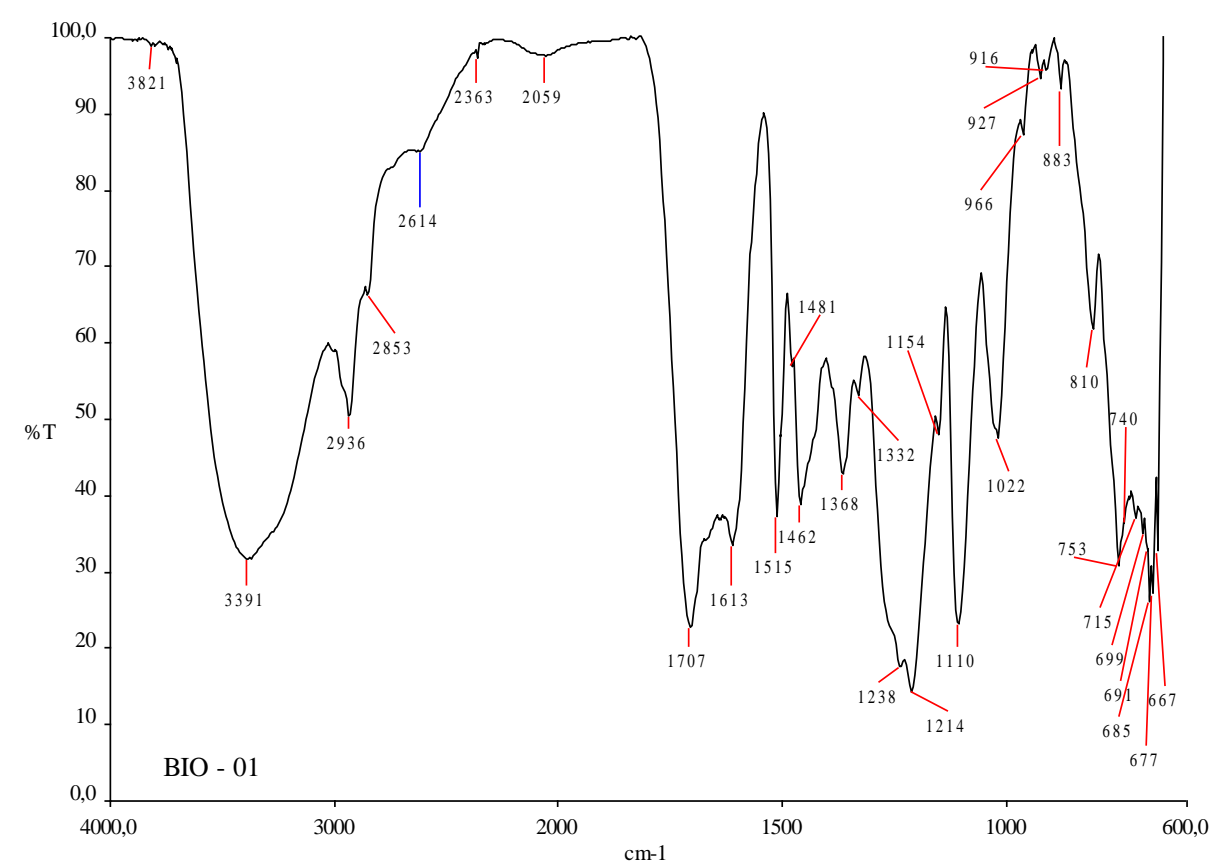

Fig. 5 IR record of pyrolysis oil from walnut shells

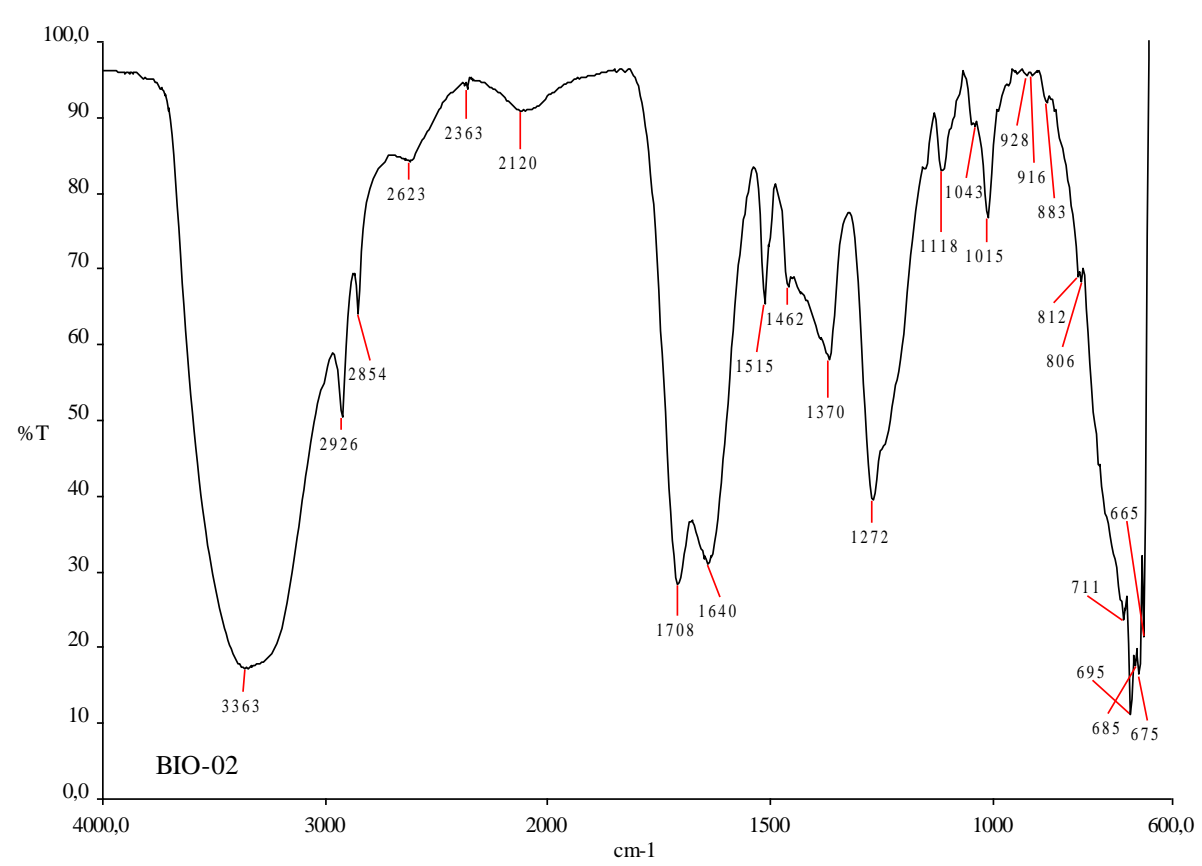

Fig. 6 IR record of pyrolysis oil from peach stones 


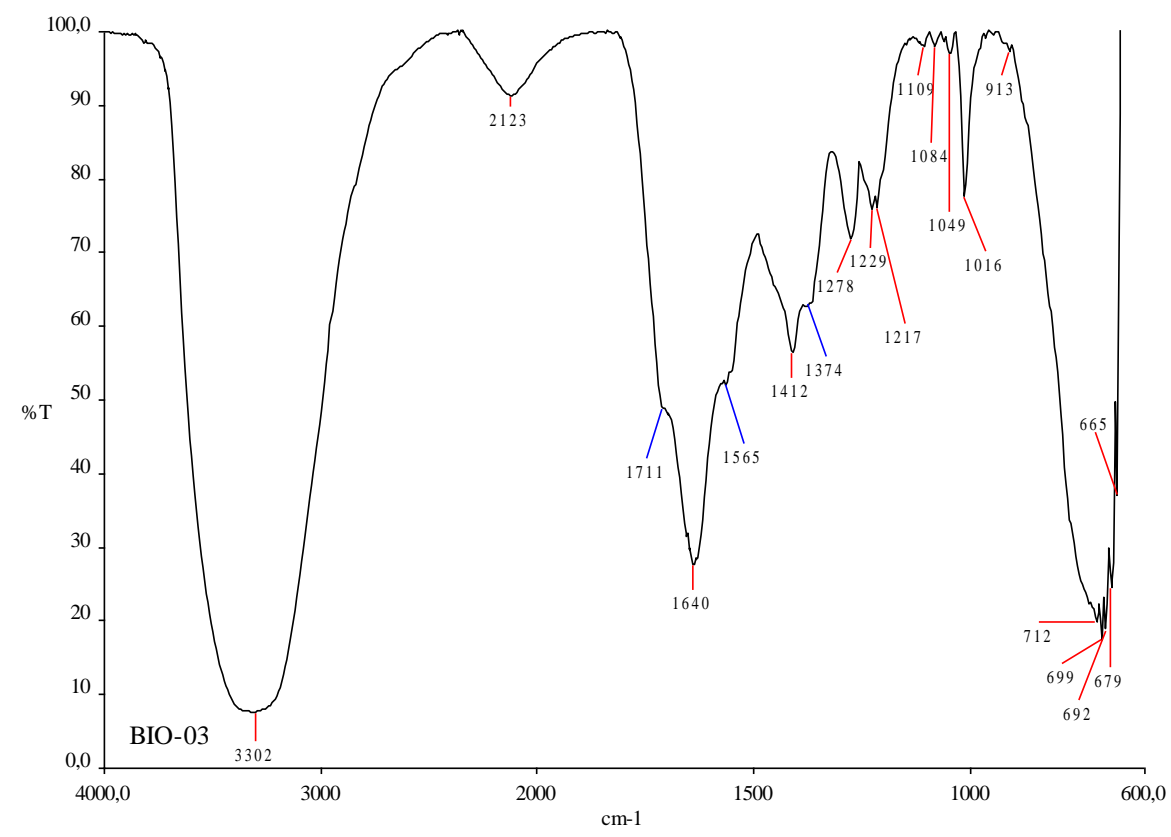

Fig. 7 IR record of pyrolysis oil from green beans

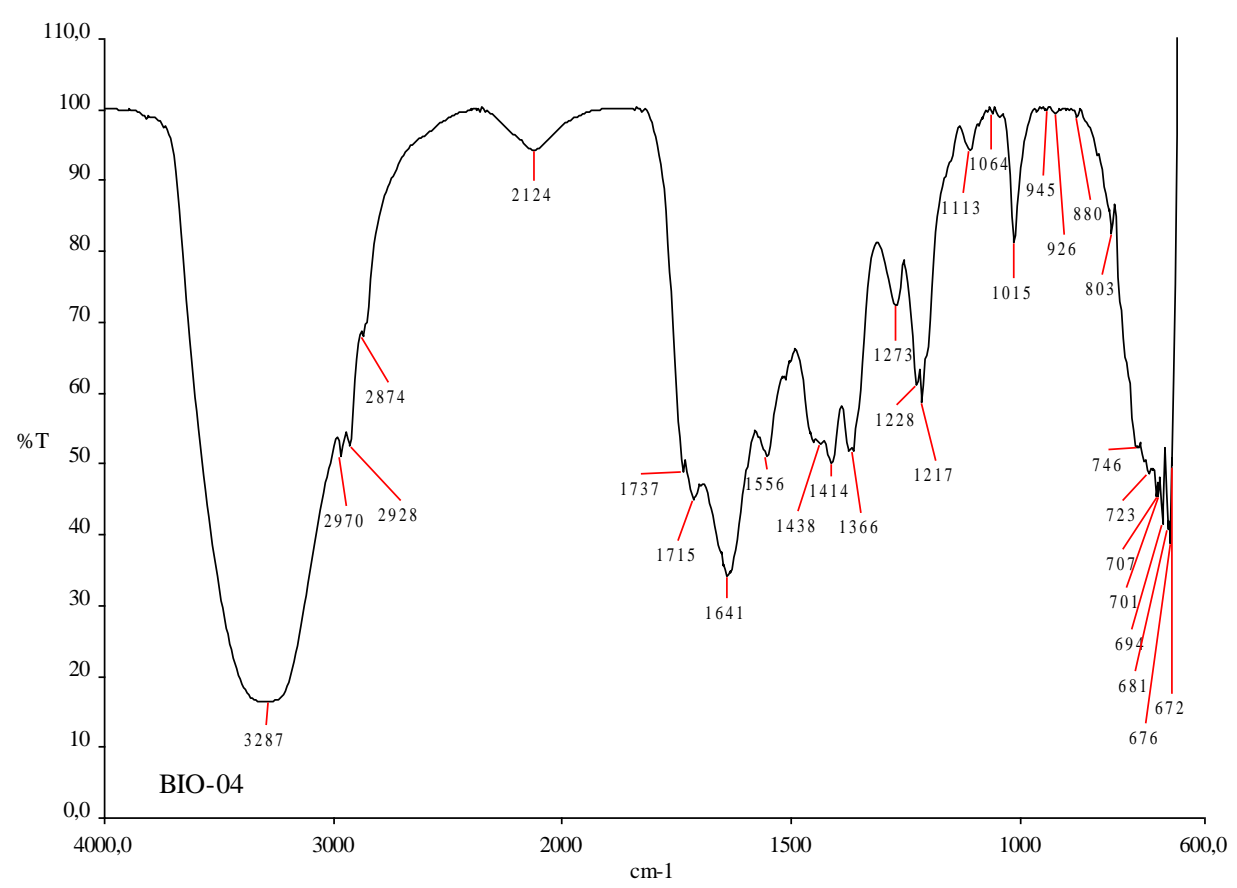

Fig. 8 IR record of pyrolysis oil from poppy heads 


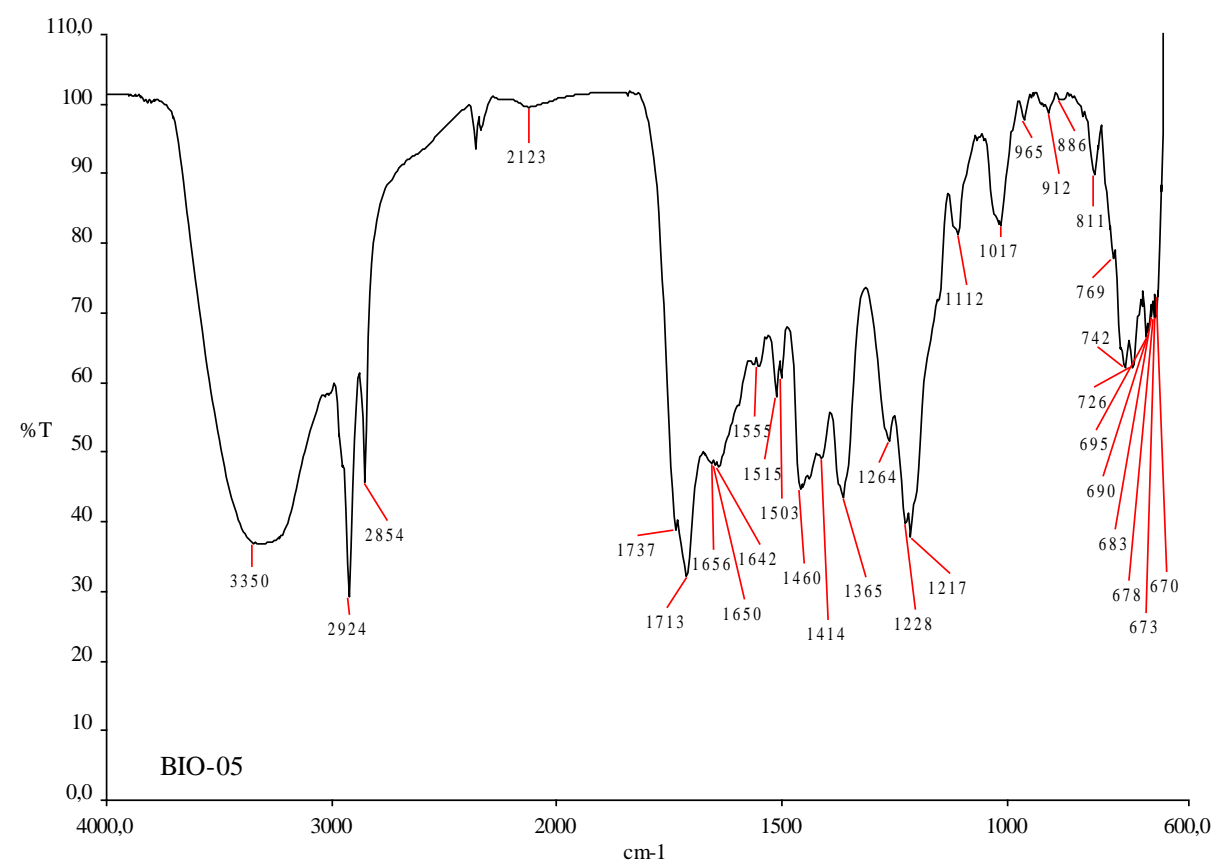

Fig. 9 IR record of pyrolysis oil from peanut shells

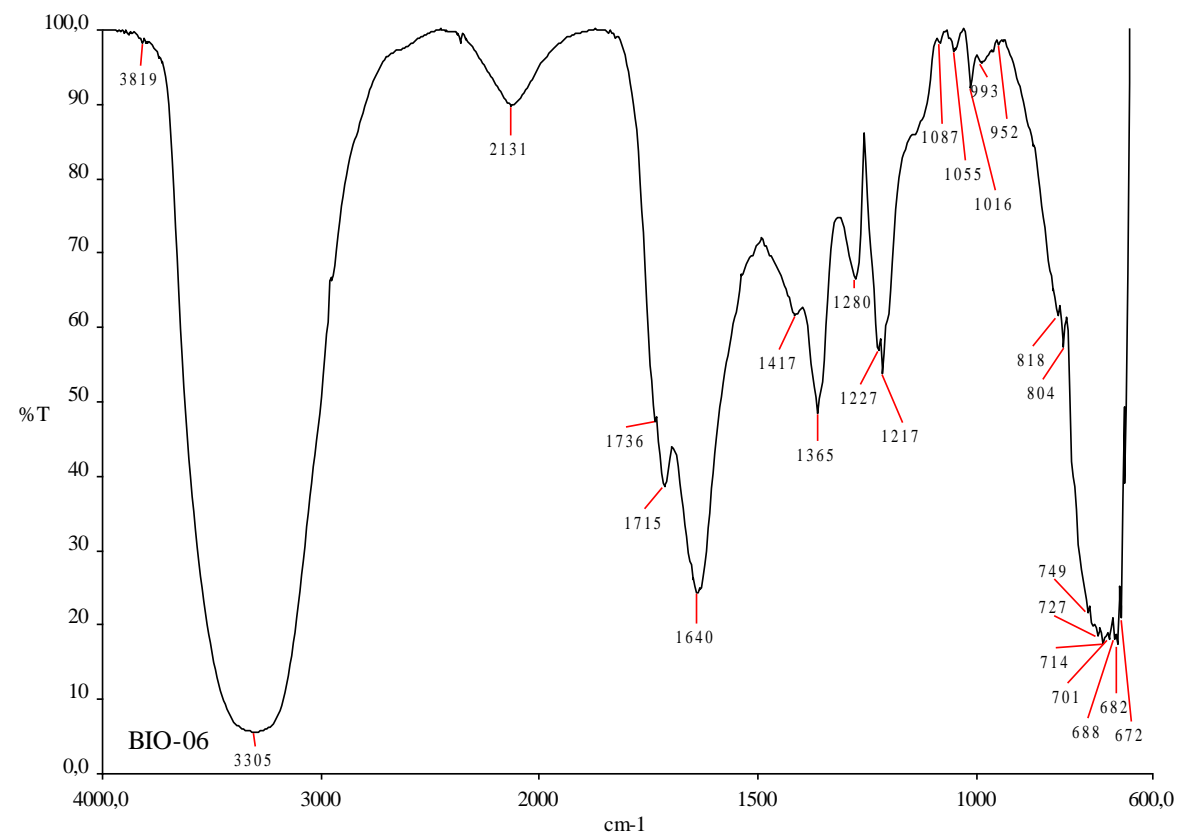

Fig. 10 IR record of pyrolysis oil from onion peel 


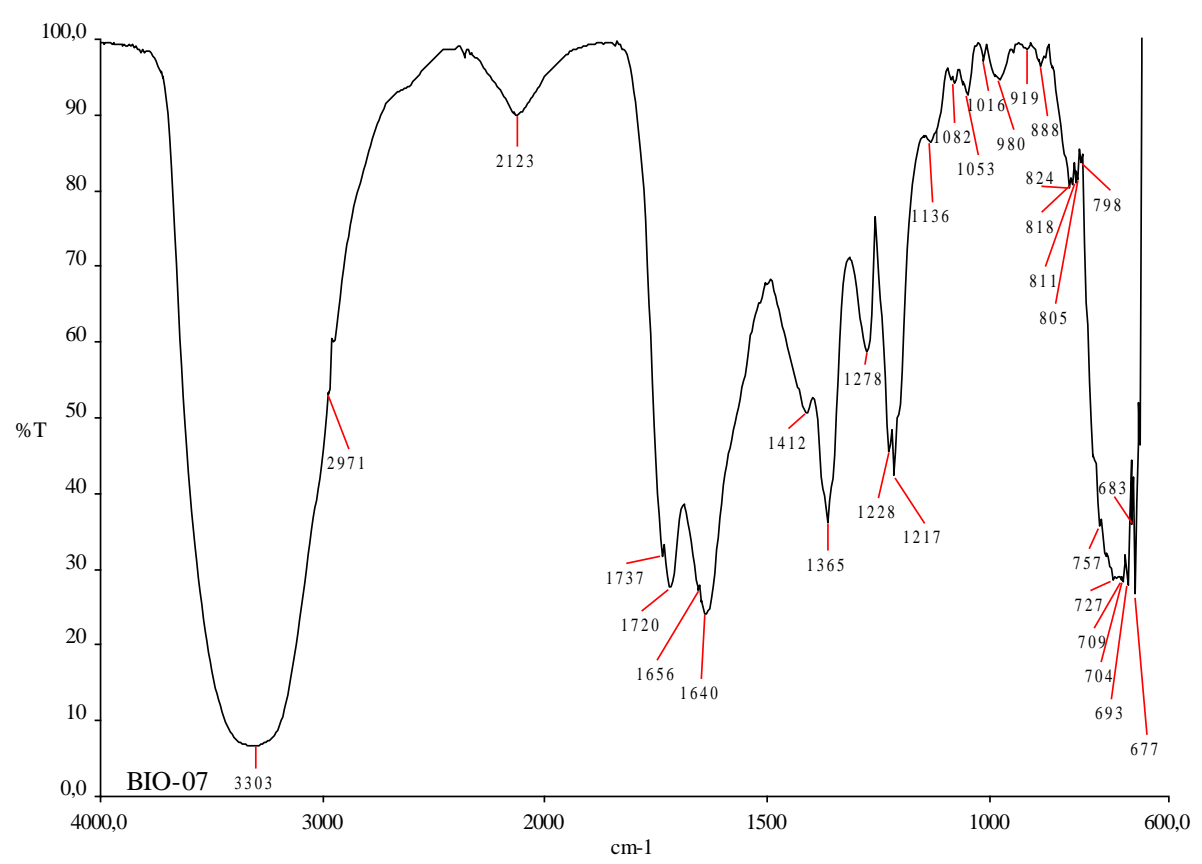

Fig. 11 IR record of pyrolysis oil from corn leaves

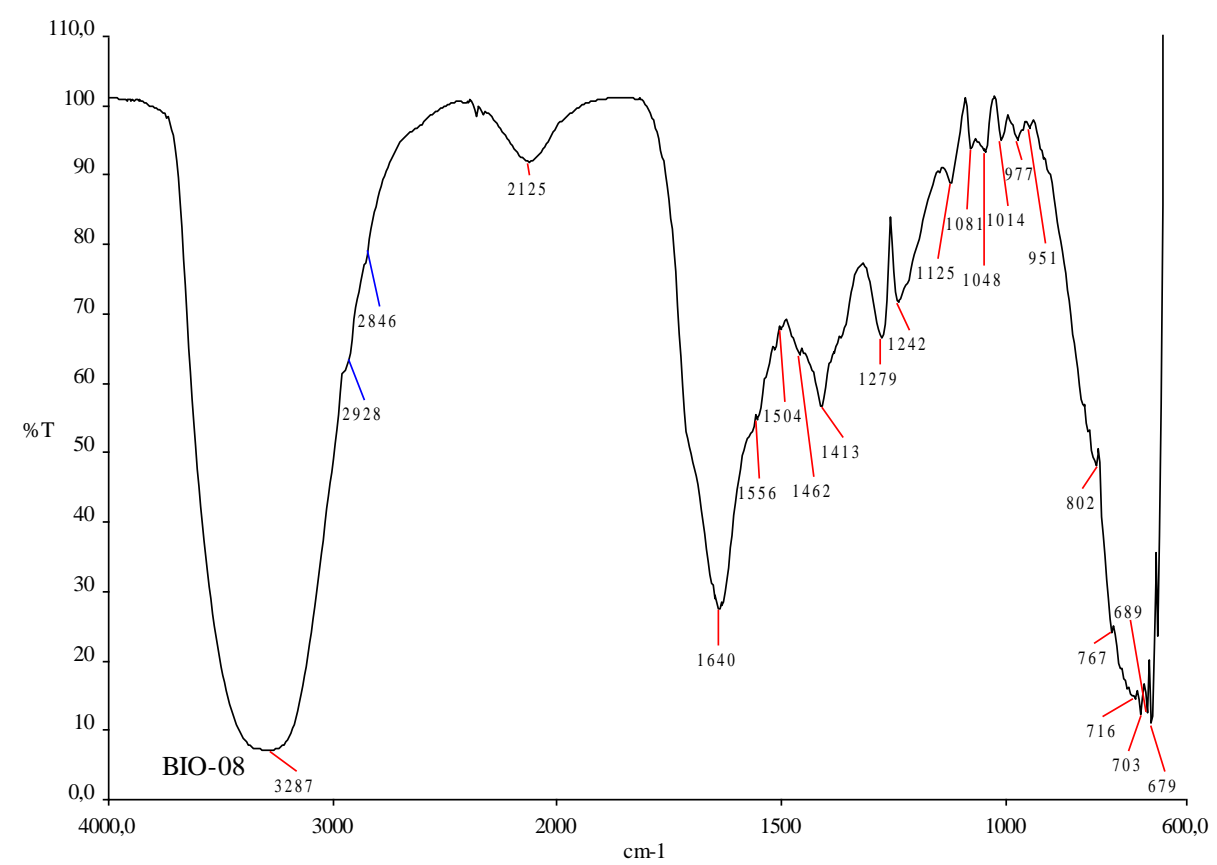

Fig. 12 IR record of pyrolysis oil from apple tree leaves 
All the samples of biological origin comprise of significant water content (wide vibration bands around $\left.3300 \mathrm{~cm}^{-1}\right)$. In the majority of sample the presence of C-H bonds in saturated hydrocarbons was proved (sharp vibration bands between 2800 and $2960 \mathrm{~cm}^{-1}$ ). The highest intensity of the peaks was in case of peanut shells. On the contrary, a very low intensity was in case of beans, onions and apple tree leaves. In the majority of samples the presence of the carbonylic group of $\mathrm{C}=\mathrm{O}$ was determined (around $1700 \mathrm{~cm}^{-1}$ ) in ketones or carboxylic acids. The presence of aromates was analyzed in walnuts and peanuts.

Flotation tests were carried out in the laboratory of the Institute of Environmental Engineering of the VSB - Technical University of Ostrava using a laboratory flotation machine VRF-1, a product of $\mathrm{RD}$ Př́bram. It is an agitating flotation machine with an own air intake. Oils produced during pyrolysis were used to test flotation oil selectivity and were compared with Montanol 551 collector.

Flotation was carried out under the following conditions:

pulp density: $150 \mathrm{~g} / \mathrm{l}$

$>$ collector dose: $500 \mathrm{~g} / \mathrm{t}$.

Tables from 2 to 10 shows the results of the individual experiments. The acquired results imply that the pyrolytic wastes from agricultural basic industry residues may be used as flotation agents. It is further apparent that the quality of the flotation concentrate is satisfactory, but when compared with Montanol 551 collector, a low weight yield was obtained and thus, later flotation tests were implemented mixing the pyrolytic collector with Montanol 551 in the proportion 1:1. Such results are given in Tables 11 to 18 . In the tables, $v$ means product yield, $K$ is concentrate, $O$ are tailings, $a$ means ash contents, $P$ is feed or input.

Tab. 2 Results of flotation tests with Montanol 551

\begin{tabular}{|l|l|l|}
\hline \multirow{2}{*}{ Montanol 551 } & $\mathbf{v}$ & $\mathbf{a}$ \\
\cline { 2 - 3 } & $\%$ & $\%$ \\
\hline $\mathrm{K}$ & 94,02 & 8,14 \\
\hline $\mathrm{O}$ & 5,98 & 78,17 \\
\hline \hline $\mathrm{P}$ & 100 & 12,33 \\
\hline
\end{tabular}

Tab. 3 Results of flotation tests with pyrolysis oil from walnut shells

\begin{tabular}{|l|l|l|}
\hline \multirow{2}{*}{$\begin{array}{l}\text { BIO 01 } \\
\text { walnut }\end{array}$} & $\mathbf{v}$ & $\mathbf{a}$ \\
\cline { 2 - 3 } $\mathrm{K}$ & $\%$ & $\%$ \\
\hline $\mathrm{O}$ & 19,17 & 8,7 \\
\hline \hline $\mathrm{P}$ & 80,83 & 13,12 \\
\hline
\end{tabular}

Tab. 4 Results of flotation tests with pyrolysis oil from peach stones

\begin{tabular}{|c|c|c|}
\hline \multirow{2}{*}{$\begin{array}{l}\text { BI } 02 \\
\text { peach }\end{array}$} & $\mathbf{v}$ & $\mathbf{a}$ \\
\hline & $\%$ & $\%$ \\
\hline $\mathrm{K}$ & 28,04 & 8,17 \\
\hline $\mathrm{O}$ & 71,96 & 11,43 \\
\hline $\mathrm{P}$ & 100 & 10,52 \\
\hline
\end{tabular}


Tab. 5 Results of flotation tests with pyrolysis oil from green beans

\begin{tabular}{|l|l|l|}
\hline \multirow{2}{*}{$\begin{array}{l}\text { BI 03 } \\
\text { beans }\end{array}$} & $\mathbf{v}$ & $\mathbf{a}$ \\
\hline $\mathrm{K}$ & $\%$ & $\%$ \\
\hline $\mathrm{O}$ & 12,1 & 7,85 \\
\hline \hline $\mathrm{P}$ & 87,9 & 13,5 \\
\hline
\end{tabular}

Tab. 6 Results of flotation tests with pyrolysis oil from poppy heads

\begin{tabular}{|l|l|l|}
\hline \multirow{2}{*}{$\begin{array}{l}\text { BI 04 poppy } \\
\text { heads }\end{array}$} & $\mathbf{v}$ & $\mathbf{a}$ \\
\cline { 2 - 3 } $\mathrm{K}$ & $\%$ & $\%$ \\
\hline $\mathrm{O}$ & 23,73 & 9,82 \\
\hline \hline $\mathrm{P}$ & 76,27 & 10,83 \\
\hline
\end{tabular}

Tab. 7 Results of flotation tests with pyrolysis oil from peanut shells

\begin{tabular}{|l|l|l|}
\hline \multirow{2}{*}{$\begin{array}{l}\text { BIO 05 } \\
\text { peanuts }\end{array}$} & v & a \\
\cline { 2 - 3 } K & 26,86 & $\%$ \\
\hline $\mathrm{O}$ & 73,14 & 8,75 \\
\hline \hline $\mathrm{P}$ & 100 & 16,75 \\
\hline
\end{tabular}

Tab. 8 Results of flotation tests with pyrolysis oil from onion peel

\begin{tabular}{|l|l|l|}
\hline \multirow{2}{*}{$\begin{array}{l}\text { BI 06 } \\
\text { onions }\end{array}$} & $\mathbf{v}$ & $\mathbf{a}$ \\
\cline { 2 - 3 } K & $\%$ & $\%$ \\
\hline $\mathrm{O}$ & 14,22 & 9,7 \\
\hline \hline $\mathrm{P}$ & 85,78 & 9,36 \\
\hline
\end{tabular}

Tab. 9 Results of flotation tests with pyrolysis oil from corn leaves

\begin{tabular}{|l|l|l|}
\hline \multirow{2}{*}{$\begin{array}{l}\text { BIO 07 corn } \\
\text { leaves }\end{array}$} & $\mathbf{v}$ & a \\
\cline { 2 - 3 } $\mathrm{K}$ & $\%$ & $\%$ \\
\hline $\mathrm{O}$ & 17,13 & 9,51 \\
\hline \hline $\mathrm{P}$ & 82,87 & 13,25 \\
\hline
\end{tabular}

Tab. 10 Results of flotation tests with pyrolysis oil from apple tree leaves

\begin{tabular}{|l|l|l|}
\hline \multirow{2}{*}{$\begin{array}{l}\text { BI } 08 \text { apple } \\
\text { tree leaves }\end{array}$} & $\mathbf{v}$ & $\mathbf{a}$ \\
\cline { 2 - 3 } $\mathrm{K}$ & 22,11 & $\%$ \\
\hline $\mathrm{O}$ & 77,89 & 8,29 \\
\hline \hline $\mathrm{P}$ & 100 & 12,89 \\
\hline
\end{tabular}


Tab. 11 Results of flotation tests with pyrolysis oil from walnut shells and Montanol 551 (1:1)

\begin{tabular}{|l|l|l|}
\hline \multirow{2}{*}{ BIO 01+Mont. 1:1 } & $\mathbf{v}$ & $\mathbf{a}$ \\
\cline { 2 - 3 } & $\%$ & $\%$ \\
\hline K & 95,85 & 10,53 \\
\hline $\mathrm{O}$ & 4,15 & 78,32 \\
\hline \hline $\mathrm{P}$ & 100,00 & 13,34 \\
\hline
\end{tabular}

Tab. 12 Results of flotation tests with pyrolysis oil from peach stones and Montanol 551 (1:1)

\begin{tabular}{|l|l|l|}
\hline \multirow{2}{*}{ BIO 02+Mont. 1:1 } & $\mathbf{v}$ & $\mathbf{a}$ \\
\cline { 2 - 3 } & $\%$ & $\%$ \\
\hline K & 93,70 & 9,35 \\
\hline $\mathrm{O}$ & 6,30 & 79,37 \\
\hline \hline $\mathrm{P}$ & 100,00 & 13,76 \\
\hline
\end{tabular}

Tab. 13 Results of flotation tests with pyrolysis oil from green beans and Montanol 551 (1:1)

\begin{tabular}{|l|l|l|}
\hline \multirow{2}{*}{ BIO 03+Mont. 1:1 } & $\mathbf{v}$ & $\mathbf{a}$ \\
\cline { 2 - 3 } & $\%$ & $\%$ \\
\hline K & 93,73 & 10,69 \\
\hline $\mathrm{O}$ & 6,27 & 70,24 \\
\hline \hline P & 100,00 & 14,42 \\
\hline
\end{tabular}

Tab. 14 Results of flotation tests with pyrolysis oil from poppy heads and Montanol 551 (1:1)

\begin{tabular}{|l|l|l|}
\hline \multirow{2}{*}{ BIO 04+Mont. 1:1 } & $\mathbf{v}$ & $\mathbf{a}$ \\
\cline { 2 - 3 } & $\%$ & $\%$ \\
\hline K & 86,69 & 7,24 \\
\hline $\mathrm{O}$ & 13,31 & 50,82 \\
\hline \hline $\mathrm{P}$ & 100,00 & 13,04 \\
\hline
\end{tabular}

Tab. 15 Results of flotation tests with pyrolysis oil from peanut shells and Montanol 551 (1:1)

\begin{tabular}{|l|l|l|}
\hline \multirow{2}{*}{ BIO 05+Mont. 1:1 } & $\mathbf{v}$ & $\mathbf{a}$ \\
\cline { 2 - 3 } & $\%$ & $\%$ \\
\hline K & 95,30 & 10,61 \\
\hline $\mathrm{O}$ & 4,70 & 73 \\
\hline \hline $\mathrm{P}$ & 100,00 & 13,54 \\
\hline
\end{tabular}


Tab. 16 Results of flotation tests with pyrolysis oil from onion peel and Montanol 551 (1:1)

\begin{tabular}{|l|l|l|}
\hline \multirow{2}{*}{ BIO 06+Mont. 1:1 } & $\mathbf{v}$ & $\mathbf{a}$ \\
\cline { 2 - 3 } & $\%$ & $\%$ \\
\hline K & 92,01 & 10,91 \\
\hline $\mathrm{O}$ & 7,99 & 55,57 \\
\hline \hline $\mathrm{P}$ & 100,00 & 14,48 \\
\hline
\end{tabular}

Tab. 17 Results of flotation tests with pyrolysis oil from corn leaves and Montanol 551 (1:1)

\begin{tabular}{|l|l|l|}
\hline \multirow{2}{*}{ BIO 07+Mont. 1:1 } & $\mathbf{v}$ & $\mathbf{a}$ \\
\cline { 2 - 3 } & $\%$ & $\%$ \\
\hline K & 93,99 & 9,78 \\
\hline $\mathrm{O}$ & 6,01 & 79,41 \\
\hline \hline $\mathrm{P}$ & 100,00 & 13,97 \\
\hline
\end{tabular}

Tab. 18 Results of flotation tests with pyrolysis oil from apple tree leaves and Montanol 551 (1:1)

\begin{tabular}{|c|r|r|}
\hline \multirow{2}{*}{ BIO 08+Mont. 1:1 } & v & \multicolumn{1}{|c|}{} \\
\cline { 2 - 3 } & \multicolumn{1}{|c|}{$\%$} & \multicolumn{1}{|c|}{$\%$} \\
\hline K & 92,03 & 10,19 \\
\hline O & 7,97 & 58,41 \\
\hline P & 100,00 & 14,03 \\
\hline \hline
\end{tabular}

It is apparent from the research results that the 1:1 proportion of the pyrolytic collector and Montanol 551is suitable and it is thus possible to obtain a satisfactory flotation concentrate quality. This way, minimum $50 \%$ of Montanol 551 collector volume, which is twice as expensive as other collectors, may be saved.

\section{CONCLUSIONS}

The objective of the article was to verify floatability of the classical collector of Montanol 551 and pyrolysis oils obtained from agricultural basic industry residues. The results imply that it is possible to produce flotation agents also from agricultural basic industry residues. In all cases, the quality of concentrates was suitable, i.e. below $10 \%$ of ash content. It is apparent from the project results that pyrolysis oils from agricultural basic industry are not toxic and it is possible to substitute up to $50 \%$ of a Montanol 551 collector dose, which may bring a significant economic effect for black coal preparation plants.

\section{REFERENCES}

[1] BEDEKOVIĆ, G., FEČKO, P., RIEDLOVÁ, S. Testing of coal flotability from mine Lazy. Conference Proceedings: $7^{\text {th }}$ Conference on Environment and Mineral Processing VŠB-TU Ostrava, 26.-28.6.2003, s. 397-402. Ostrava, 2003. ISBN 80-248-0248-1.

[2] BEDEKOVIĆ, G., FEČKO, P., RIEDLOVÁ S., DROBÍK M. Testováni flotačnich sběraču na vzorcích uhlí z dolu Lazy. Sborník: Recyklace odpadů VII, VŠB-TU Ostrava. 10.X.2003, s. 149154. Ostrava, 2003. ISBN 80-248-0245-7. 
[3] CROZEIR, R. D. Flotation - theory, reagents and ore testing. Pergamon Press, 1992. ISBN 008-041864-3.

[4] FEČKO, P. Netradiční způsoby úpravy černouhelných kalů. VŠB-TU Ostrava, 2001. $150 \mathrm{~s}$. ISBN 80-7078-921-2.

[5] FEČKO, P., OVČǍ̌́, P., RIEDLOVÁ, S., SKÓRKA, V., TORA, B. The Investigation on the flotation of coal from mine Staszicz (Poland). $12^{\text {th }}$ International Conference on Coal Science, Cairns, Australia, 2.-6.11.2003, ref.12P $\alpha$.

[6] FEČKO, P., PEČTOVÁ, I., RIEDLOVÁ, S., KUČEROVÁ, R. Testing of Coal Floatability from Mine CSA. Conference Proceedings: Proceedings of 10th International Mineral Processing Sympozium, Cesme, Turkey, 5.-7.X.2004, s. 927-934. ISBN 975-7946-21-4.

[7] GEBHARDT, J. E., MANKOSA, M. J., LEE, K. Y., BROUSSAUD, A. Fine coal flotation in the Microcel $^{T M}$ column. Proceedings of the 12th International Coal Preparation Congress, Cracow, Poland, May 23-27, 1994, s. 773-778. ISBN 2-88449-139-2.

[8] KMEŤ, S. Flotácia. Vydavatel'stvo Alfa, Bratislava, 1992. 289 s. ISBN 80-05-00971-2.

[9] LASKOWSKI, J. Coal Flotation and Fine Coal Utilization. Elsevier, Amsterdam, 2001. 368 s. ISBN 0-444-50537-7.

[10] ROUBÍČEK, V., BUCHTELE, J. Uhlí, zdroje, procesy, užití. Ostrava, MONTANEX, 2002. 173 s. ISBN 80-7225-063-9.

[11] ROUBÍČEK, V., BUCHTELE, J. Chemie uhli a jeho využití. VŠB-TU, Ostrava 1996. 216 s. ISBN 80-7078-406-7.

[12] SABLIK, J. Flotacja wegli kamenných. GIG Katovice, 1998. s. 291. ISBN 83-87610-02-X.

\section{RESUMÉ}

Cílem práce bylo ověřit flotovatelnost klasického sběrače Montanol 551 a pyrolyzních olejů získaných z odpadů zemědělské prvovýroby. Z výsledků vyplývá, že i z odpadů zemědělské prvovýroby lze vyrobit flotační činidla. Ve všech př́ípadech byla kvalita koncentrátů vyhovující, tj. pod $10 \%$ obsahu popela. $Z$ výsledků projektu je zřejmé, že pyrolyzní oleje z odpadů zemědělské prvovýroby nejsou toxické a že lze nahradit až $50 \%$ dávky sběrače Montanol 551, což může přinést významný ekonomický efekt úpravnám černého uhlí. 